\title{
ISLAMIC VALUES AS REFLECTED IN THE ENGLISH TEACHING AND LEARNING PROCESS AT MA MUSLIMAT NU PALANGKA RAYA
}

\author{
Aula Mukarramah ${ }^{1}$, Sabarun $^{2}$, Zaitun Qamariah ${ }^{3}$ \\ 1,2,3 State Islamic Institute of Palangka Raya \\ ${ }^{1}$ aulamukarramah@gmail.com, ${ }^{2}$ sabarun@iain-palangkaraya.co.id, ${ }^{3}$ zaitunqamariah@ gmail.com
}

\begin{abstract}
The research was aimed at describing Islamic values in the English teaching and learning process at MA Muslimat NU Palangka Raya. This research focused on describing the English teaching and learning process that reflected Islamic values by English teachers. This research used a descriptive qualitative approach to find out facts and describe phenomena. These research subjects were English teachers of the tenth and the eleventh grade at MA Muslimat NU Palangka Raya. The data in this research results from observations of the learning process and the result of an interview with the English teachers and documentation. The finding found that reflection done by the teachers was in the lessons as follows. First, the teachers did the reflection in three sessions of the lessons, they are (1) the reflection of Islamic values in opening activity, (2) the reflection of Islamic values in the main activity, and (3) the reflection of Islamic values in the closing activity. Second, the opening and closing sessions were by conducted code-switching and code-mixing between English and Islamic expressions. Third, in the main activity, there are several ways to materials development such as (a) adding the example or exercise of the material presented that reflecting the Islamic values, (b) people, place, an event used Islamic names (c) linking the topic with the verses Al-Qur'an that suitable materials and (d) gave the assignment that related to the Islamic values to write a kind of text concerned to the topic material.
\end{abstract}

Keywords: Islamic Values, Reflect, Teaching and Learning Process

\section{INTRODUCTION}

English is an academic need and a global language that plays a role in global communication and interaction and progress, development, and competition as a world communication language. In his writing, McKay (2003) states that English's popularity is not an attempt at the first category of countries (inner circle countries) to spread their language and the world community's awareness of the importance of mastering English. Because of the importance of learning English, the Indonesian government included the English language in the study curriculum at schools and also Islamic schools.

Islamic school is essentially a school that employs Islamic education concepts based on the Qur'an and Sunnah, but at an English lesson, it was not touched by Islamic values. There needs to be English teacher creativity or English book authors' creativity at Islamic School to realize their expectations. The material covers all learning material that students will learn Islamic values.

Besides, the teachers should also be a role models for students in Islamic values practice. Islamic school in education is predicted to contribute an effective potential in shaping Muslims who are able and ready to practice Islam's teachings in their routines. An essential example for guiding students to practice Islam's teaching is religious education teachers and other general knowledge teachers. 
Moreover, this research attempts to solve the problem of dualism faced by Muslim education in this contemporary world resulted from the dualistic system of education, religious and secular division. In other words, there should not be segregation between religious and non-religious education in Islamic education. Both of them should be unified and reflected. Hence, the reflected Islamic values are proposed to be the best resolution in solving dualism in Muslim education.

This research tried to answer the problem, how is the reflection of Islamic values in the English teaching and learning process at MA Muslimat NU Palangka Raya?. This research aims to describe the reflection of Islamic values in the English teaching and learning process at MA Muslimat NU Palangka Raya.

\section{METHOD}

This research used a qualitative approach with descriptive methods. According to Saryono (2010), qualitative research is a study used to investigate, find, describe, and explain the quality or privilege of social influences that cannot be explained, measured, or described through a qualitative approach. This research aims to gain data in the field consists of field note for observation, transcript for interview, and documentation. The researcher chooses this method to excavate information that appropriates with pieces of evidence in the field then analyzed with a theory that has been there.

The research subjects were the English teachers and students of the tenth and eleventh MA Muslimat NU Palangka Raya grades. The object of research was the process of reflecting Islamic values in the English teaching and learning process. The researcher chooses the subject based on the purposive sampling criteria. Purposive sampling was selected based on the characteristics of a population and the purpose of the research. This research was aimed to gain data in the field consists of observation, interview, and documentation.

Table. 1

Students of tenth and eleventh of MA. Muslimat NU Palangka Raya

\begin{tabular}{cc}
\hline \multicolumn{2}{c}{ Students of tenth and eleventh of MA Muslimat NU Palangka Raya } \\
\hline X IPA & 43 \\
\hline X IPS & 44 \\
\hline XI IPA & 44 \\
\hline XI IPS & 44 \\
\hline Total & $\mathbf{1 7 5}$ \\
\hline
\end{tabular}

Researcher answering questions that have been formulated use data analysis techniques. Thus, the researcher use Miles \& Huberman's (1994) design includes of Data Collection, Data Reduction, Data Display, and Drawing Conclusion.

\section{RESULTS AND DISCUSSION}

\section{Results}

The research findings of Islamic values reflection based on the study of the reflection of values in the lessons were analyzed by the table of Islamic value reflection in teaching-learning process. To reflect the values can be carried out from opening, main activity, and closing. The table is composed of the studies. The researcher accessible to analyze the data used code.

The coding of the data:

1. A : for Mrs. Nor Harisha, S.Pd

2. B : for Mr. Zulfikar Hamzah, S.Pd 
Here the following table:

Table. 2

Result of Observation Islamic Value Reflection in Teaching English and learning process

\begin{tabular}{|c|c|c|c|c|c|}
\hline \multirow[b]{2}{*}{ Teacher } & \multirow[b]{2}{*}{ Class } & \multirow[b]{2}{*}{ Time } & \multicolumn{3}{|c|}{ Islamic Value Reflection } \\
\hline & & & Opening & $\begin{array}{l}\text { Main- } \\
\text { activity }\end{array}$ & Closing \\
\hline A & X IPA & January $25^{\text {th, }} 2021$ & $\sqrt{ }$ & - & $\sqrt{ }$ \\
\hline A & X IPS & January $26^{\text {th, }} 2021$ & $\sqrt{ }$ & $\sqrt{ }$ & $\sqrt{ }$ \\
\hline $\mathrm{B}$ & XI IPA & January $27^{\text {th, }} 2021$ & $\sqrt{ }$ & $\sqrt{ }$ & $\sqrt{ }$ \\
\hline B & XI IPS & January $28^{\text {th, }} 2021$ & $\sqrt{ }$ & $\sqrt{ }$ & $\sqrt{ }$ \\
\hline $\mathrm{A}$ & X IPA & February $1^{\text {st }}, 2021$ & $\sqrt{ }$ & $\sqrt{ }$ & $\sqrt{ }$ \\
\hline A & X IPS & February $2^{\text {nd }}, 2021$ & $\sqrt{ }$ & $\sqrt{ }$ & $\sqrt{ }$ \\
\hline $\mathrm{B}$ & XI IPA & February $3^{\text {rd }}, 2021$ & $\sqrt{ }$ & $\sqrt{ }$ & $\sqrt{ }$ \\
\hline $\mathrm{B}$ & XI IPS & February $4^{\text {th, }} 2021$ & $\sqrt{ }$ & $\sqrt{ }$ & $\sqrt{ }$ \\
\hline
\end{tabular}

The table showed the related focus of this research. Here the following explanation:

a. Teacher A, First observation (January, $\mathbf{2 5}^{\text {th }} \mathbf{2 0 2 1}$ )

The researcher researched in the tenth grade of science studies of MA Muslimat NU Palangka Raya. In this lesson, the topic about simple past and present perfect tense. The result of the table was did the reflection Islamic values in the opening and closing of the English teaching and learning process.

1) Opening

The opening session included the indicator of Islamic values. There is a religion that the teacher greets the students by said "Salam" and the teacher gives instruction to the student for praying together.

2) Closing

The closing session included the indicator of Islamic values, which are independent, peace-loving, and religion. First, independent is that the teacher and students conclude the result of today's material. Then, peace-loving is that the teacher gives the motivation to be thankful for everything that God gives and always have scientists thinking in daily life. The last religion is that the teacher closed the learning by "salam".

\section{b. Teacher A, second observation (January, $\mathbf{2 6}^{\text {th }} \mathbf{2 0 2 1}$ )}

The researcher researched in the tenth-grade social studies of MA Muslimat NU Palangka Raya. In this lesson, the topic about simple past and present perfect tense. The result of the table was did the reflection Islamic values in the opening, main-activity, and closing of the English teaching and learning process.

1) Opening

The opening included the indicator of Islamic values. There is a religion that is The teacher greets the students by said "Salam" and the teacher gives instruction to the student for praying together.

2) Main-activity

The main activity included indicators of Islamic values: independent, friendly, socially concerned, and honest. First, the independent is that the teacher asked to explain the simple past and present perfect tense. Thrid, friendly is that the teacher explained the 
example one by one, and the teacher uses a Muslim's name in this example. Then, socially concern is that the student helps her friend to answer a question. The last honest is about their understanding of the material.

3) Closing

The closing session included the indicator of Islamic values, which are independent, peace-loving, and religion. First, independent is that the teacher and students conclude the result of today's material. Then, peace-loving is that the teacher gives the motivation to be thankful for everything that God gives and always have scientists thinking in daily life. The last, religion is that the teacher closed the learning by "salam".

\section{c. Teacher B, third observation (January, 27 ${ }^{\text {th }} \mathbf{2 0 2 1}$ )}

The researcher researched in the eleventh-grade science studies of MA Muslimat NU Palangka Raya. In this lesson, the material about the personal letters. The result of the table was did the reflection Islamic values in the opening, main-activity, and closing of the English teaching and learning process.

1) Opening

The opening included the indicator of Islamic values. There is a religion that the greets by said "Assalamualaikum" and the students replied it together, and the teacher saying, "how are you today? Have you had breakfast yet?" to know the condition of the student. Then, the teacher gives instructions to a student to leads the prayer to start the lesson.

2) Main-activity

The main activity included indicators of Islamic values. There are democratic, curious, and patriotic. Democratic in this teaching-learning, the student listened, asking, expressing the opinion of the teacher's explanation about the personal letter. Moreover, there is curious is that the teacher read a more example given by a teacher about a best friend's letter. The last, patriotic is that the teacher gives the example of how a Muslim writes a letter.

3) Closing

The closing of the class included indicators of Islamic values. There are curious, friendly, and religion. First, the curious is that the teacher asked the students about difficulties while the learning process. Then, friendly is that the student gives her opinion while discussing and the last, religion is that the teacher asks the captain to lead the prayer to close the lesson. Finally, the teacher greets the students by saying goodbye, see you next week, and "Salam".

\section{d. Teacher B, fourth observation (January, $28^{\text {th }} \mathbf{2 0 2 1}$ )}

The researcher researched in the eleventh-grade social studies of MA Muslimat NU Palangka Raya. In this lesson, the material about the personal letters. The result of the table as did the reflection Islamic values in the opening, main-activity, and closing of the English teaching and learning process.

1) Opening

The opening included the indicator of Islamic values. There is a religion that the greets by said "Assalamualaikum" and the students replied it together, and the teacher saying, "how are you today? Have you had breakfast yet?" to know the condition of the 
student. Then, the teacher gives instructions to a student to leads the prayer to start the lesson.

2) Main-activity

The main activity included indicators of Islamic values. There are democratic, curious, and patriotic. Democratic in this teaching-learning, the student listened, asking, expressing the opinion of the teacher's explanation about the personal letter. Moreover, there is curious is that the teacher read a more example given by a teacher about a best friend's letter. The last, patriotic is that the teacher gives the example of how a Muslim writes a letter.

3) Closing

The closing of the class included indicators of Islamic values. There are curious, friendly, and religion. First, the curious is that the teacher asked the students about difficulties while the learning process. Then, friendly is that the student gives her opinion while discussing and the last, religion is that the teacher asks the captain to lead the prayer to close the lesson. Finally, the teacher greets the students by saying goodbye, see you next week, and "Salam".

\section{e. Teacher A, fifth observation (February, $1^{\text {st }}$ 2021)}

The researcher researched in the tenth-grade science studies of MA Muslimat NU Palangka Raya. In this lesson, the material about recount text. The result of the table was did the reflection Islamic values in the opening, main-activity, and closing of the English teaching and learning process.

1) Opening

The opening included the indicators of Islamic values. There are religion and discipline. First, religion is that the teacher greets by said "Salam" and the last, discipline is all of the students had done their homework in time.

\section{2) Main-activity}

The main activity included indicators of Islamic values there are democratic, curious, patriotic, and friendly. First, democratic is that the teacher explains all about recount text, include definition, structure, purpose, characteristics, and the type of recount text. Moreover, there is curious that the teacher gave time to understand the recount text's meaning for the students. Then, patriotic is that the teacher explained recount text to the students briefly and practice as the teacher's order in their daily life. The last, friendly is that the students ask their friends when their want to know of the topic.

3) Closing

The closing of the class included indicators of Islamic values there are independent, fond of reading, peace-loving, and religion. First, independent is that the teacher asks whatever the students have a problem in the teaching-learning process. Second, fond of reading is that the teacher and students conclude the result of today's material. Then, peace-loving is that the teacher gives the motivation to be thankful for everything that God gives and always have scientists thinking in daily life. The last, religion is that the teacher closed the learning by "salam". 


\section{f. Teacher A, sixth observation (February, $2^{\text {nd }}$ 2021)}

The researcher researched in the tenth-grade social studies of MA Muslimat NU Palangka Raya. In this lesson, the material about recount text. The result of the table was did the reflection Islamic values in the opening, main-activity, and closing of the English teaching and learning process.

1) Opening

The opening included the indicators of Islamic values. There are religion and discipline. First, religion is that the teacher greets by said "Salam" and the last, discipline is all of the students had done their homework in time.

2) Main-activity

The main activity included indicators of Islamic values there are democratic, curious, patriotic, and friendly. First, democratic is that the teacher explains all about recount text, include definition, structure, purpose, characteristics, and the type of recount text. Moreover, there is curious that the teacher gave time to understand the recount text's meaning for the students. Then, patriotic is that the teacher explained recount text to the students briefly and practice as the teacher's order in their routines. The last, friendly is that the students ask their friends when their want to know of the topic.

3) Closing

The closing of the class included indicators of Islamic values there are independent, fond of reading, peace-loving, and religion. First, independent is that the teacher asks whatever the students have a problem in the teaching-learning process. Second, fond of reading is that the teacher and students conclude the result of today's material. Then, peace-loving is that the teacher gives the motivation to be thankful for everything that God gives and always have scientists thinking in daily life. The last, religion is that the teacher closed the learning by "salam".

\section{g. Teacher B, seventh observation (February, $3^{\text {rd }}$ 2021)}

The researcher researched in the eleventh-grade science studies of MA Muslimat NU Palangka Raya. In this lesson, the material about cause and effect. The result of the table was did the reflection Islamic values in the opening, main-activity, and closing of the English teaching and learning process.

\section{1) Opening}

The opening included the indicator of Islamic values. There is a religion in that the teacher greets by said "Assalamualaikum" and the students replied it together, also asked by saying, "how are you today? Have you had breakfast yet?". Then, the teacher gives instructions to a student to leads the prayer to start the lesson.

2) Main-activity

The main activity included indicators of Islamic values. There are friendly, curious, and patriotic. First, friendly is that The teacher explains the materials. Then, curious is that the teacher gives an example about cause and effect text and students were ordered to read and analyze the text. The last, patriotic is that in the text about fasting, the teacher's reflection, what the benefit when someone was fasting was mentioned in our holy Quran.

\section{3) Closing}


The closing included an indicator of Islamic value. There is a religion that the teacher asks the captain of the class to lead the pray before closing the lesson, and the teacher greets the students by saying goodbye, see you next week, and Salam.

\section{h. Teacher B, eighth observation (February, $4^{\text {th }}$ 2021)}

The researcher researched in the eleventh-grade science studies of MA Muslimat NU Palangka Raya. In this lesson, the material about cause and effect. The result of the table was did the reflection Islamic values in the opening, main-activity, and closing of the English teaching and learning process.

1) Opening

The opening included the indicator of Islamic values. There is a religion in that the teacher greets by said "Assalamualaikum" and the students replied it together, also asked by saying, "how are you today? Have you had breakfast yet?". Then, the teacher gives instructions to a student to leads the prayer to start the lesson.

2) Main-activity

The main activity included indicators of Islamic values. There are friendly, curious, patriotic, and hardworking. First, friendly is that The teacher explains the materials. Second, curious is that the teacher gives an example about cause and effect text, and students were ordered to read and analyze the text. Then, patriotic is that in the text about fasting, the teacher reflection, what the benefit when someone was fasting was mentioned in our holy Quran. The last, hardworking or discipline is that finish their task carefully in time.

3) Closing

The closing included an indicator of Islamic values. There are peace-loving and religion. First, peace-loving is that The teacher delivers massages to always comply with health protocols, including washing hands with soap, keeping a distance, and consuming food or drinks to increase the body's immunity. Last, religion is that the teacher asks the class captain to lead the prayer before closing the lesson, and the teacher greets the students by saying goodbye, seeing you next week, and Salam.

From observations done by the researcher, the result showed that the teacher did do the session of reflection on Islamic values consecutively. The sequent sessions of reflection included the opening session, main-activity session, and closing session.

\section{Discussion}

In the results, the researcher explained the reflection of Islamic values in English teaching and learning done by the teachers at MA Muslimat NU Palangka Raya revealed several considerations. The findings revealed that (1) The teachers did the reflection in three-session in the English teaching and learning process; they are (a) the reflection of Islamic values in opening activity, (b) the reflection of Islamic values in the main activity, and (c) the reflection of Islamic values in the closing activity. (2) The opening and closing activities were conducted by conducting code-switching and code-mixing between Islamic expressions and English, such as "Assalamualaikum" and "How are you?". (3) In the main activity, there are material developments done through several ways, such as (a) adding the example or exercise of the material presented that reflecting the Islamic values, (b) people, place, an event used Islamic names (c) linking the topic with the verses Al-Qur'an that suitable materials and (d) gave the assignment that related to the Islamic values to write a kind of text concerned to the topic material. 
The finding was in accordance with Adnan (2020). He found that the teacher did the Islamic value internalization in three stages of main-activity, they are (1) knowledge transfer stage, (2) transaction stage, and (3) trans-internalization stage. It is in line with Lubis (2016), who assist that during the learning process carried out by English teachers in the classroom, starting from the opening process of learning to the process of closing learning. The finding was also supported by Sunarto (2014), who pointed out that the teacher conducted code-mixing and code-switching between English and Islamic expressions for greetings. This finding was in line with Hadijah \& Annisa (2017), in her research, the integration was done by embedding the Islamic values supported by verses of Al-Quran or Al-Hadits relevant to the main material selected based on predetermined instructional objectives. In another research by Zaitun \& Wardani (2018), she found that the syllabus consists of Basic Competence, Materials, Learning Activities, Competence Achievement Indicators, Assessment, Time Allotment, and Learning Sources. It can be seen from the Standard Competence of each language skill that there are no Islamic values stated on this component and the learning activities.

\section{CONCLUSION}

Based on the results, and discussion about the reflection of Islamic values in the English teaching and learning process at MA Muslimat NU Palangka Raya, the researcher drew a conclusion which answers the problem statement based on the result of the research related to reflection of Islamic values in English teaching and learning process, the result showed that (1) The teachers did the reflection in three-session in the English teaching and learning process; they are (a) the reflection of Islamic values in opening activity, (b) the reflection of Islamic values in the main activity, and (c) the reflection of Islamic values in the closing activity. (2) The opening and closing activities were conducted by conducting code-switching and codemixing between Islamic expressions and English, such as "Assalamualaikum" and "How are you?". (3) In the main activity, there are material developments done through several ways, such as (a) adding the example or exercise of the material presented that reflecting the Islamic values, (b) people, place, an event used Islamic names (c) linking the topic with the verses AlQur'an that suitable materials and (d) gave the assignment that related to the Islamic values to write a kind of text concerned to the topic material.

\section{ACKNOWLEDGMENTS}

The researcher would like to express her sincere gratitude to Allah SWT. for the blessing bestowed in whole life particularly during the jurnal writing without which this jurnal would not have come to its final form. Sholawat and salam always be bestowed to the last prophet Muhammad SAW. This article entitled "Islamic Values As Reflected in The English Teaching and Learning at MA. Muslimat NU Palangka Raya" is submitted in partial fulfillment of the requirements for the degree of Sarjana in English Language Education IAIN Palangka Raya.

\section{REFERENCES}

Adnan, M. (2020). Internalisasi Nilai-Nilai Kemandiriandi SMP It Harapan Bunda Purwokerto Kabupaten Banyumas. Institut Agama Islam Negeri Purwokerto.

Hadijah, S., \& Annisa. (2017). The integration of Islamic values in English teaching and learning process at MAN Model Palangka Raya. International Conference on English Language Teaching (INACELT).

Lubis, R. F. (2016). Analysis of Integrated Values in English Learning In Tsanawiyah 
Education In Padangsimpuan City. Jurnal Penelitian Ilmu-Ilmu Sosial Dan Keislaman, 2. McKay, S. (2003). Teaching English as an International Language. ELT Journal, 57, 139-148.

Miles, M. B., \& Huberman, A. M. (1994). Analisis Data Kualitatif (T. R. Rohidi, Ed.). Jakarta: Universitas Indonesia Press.

Saryono. (2010). Metode Penelitian Kualitatif. Bandung: PT Alfabeta.

Sunarto. (2014). The Integration of Islamic Values in English Teaching and Learning at SD Islam Terpadu Al-Mumtaz kota Pontianak. Yogyakarta: Universitas Yogyakarta.

Zaitun, \& Wardani, S. K. (2018). Islamic values in the context of English learning and teaching. English Language in Focus (ELIF), 1(1), 70-80. 